\title{
WABI SABI: INTERMEDIATED TEXTURES OF IMPERMANENCE AND IMPERFECTION
}

\author{
WABI SABI: TEXTURAS INTERMEDIADAS DE IMPERMANENNCIA E \\ IMPERFEIÇÃO
}

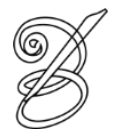

Paul VENZO*

Deakin University, Australia

\begin{abstract}
Mark Reibstein and Ed Young's 2008 picture book Wabi Sabi tells the story of a Kyoto cat in search of the meaning of its name. This award-wining children's book explores identity through the composition of various layers of meaning and complexity in form and structure, suggesting that an understanding of identity cannot be expressed easily through words alone. This paper begins by examining how the use of a range of storytelling modes including collage, photography, drawing, poetry and prose are combined, inviting the implied child reader to become involved in the intermedial qualities of the text, at the same time as they follow the cat in its journey of self-discovery. Focus then turns to the use of natural, textured materials in the artwork of the picture book, analyzed as a reflection of the concept of wabi sabi; a Zen-Taoist philosophy that draws attention to the value and beauty of impermanence and imperfection. This alternative way of thinking about identity proposes that self-knowledge is attained through an encounter with simple, rustic and natural phenomena, as opposed to the industrialized newness and perfection so often idealized in Western civilization. The third section of the paper explores how the text, with its capacity to incorporate both Western and Japanese modes of storytelling, is a form of cultural translation. Not confined to the traditional mode of translation from one language to another, or from source to target text, this picture book, in its use of haiku and Japanese calligraphy, its glossary and its explanation of wabi sabi, invites the reader to consider how translation shares ideas across and between time and cultural context.
\end{abstract}

Keywords: Intermediation. Transculturality. Translation. Wabi Sabi. Children's Literature.

Resumo: O livro ilustrado Wabi Sabi (2008), de Mark Reibstein e Ed Young's, narra a história de um gato de Kyoto em busca do significado de seu nome. Esse premiado livro infantil explora a identidade por meio da composição de várias camadas de significado e complexidade na forma e na estrutura, sugerindo que uma compreensão da identidade não pode ser facilmente expressa apenas por palavras. Este artigo começa por examinar como o uso de uma gama de formas de contar histórias, incluindo colagem fotografia, desenho, poesia e prosa são combinados, convidando o leitor infantil implícito a envolver-se na natureza intermidiática do texto, a mesmo tempo em que segue o gato em sua jornada de auto-descoberta. Em seguida, o foco se volta para o uso de materiais naturais e texturizados na arte do livro ilustrado, considerados na análise como um reflexo do conceito de wabi sabi: uma filosofia Zen-Taoísta que chama a atenção para o valor e a beleza da impermanência e da imperfeição. Este modo alternativo de pensar a identidade propõe que o auto-conhecimento é alcançado pelo encontro com fenômenos simples, rústicos e naturais, em oposição à novidade e à perfeição industrializada tão frequentemente idealizada na civilização ocidental. A terceira seção do artigo explora como o texto, com sua capacidade para incorporar tanto o modo ocidental quanto o modo japonês de contar histórias, é uma forma de tradução cultural. Sem estar confinado ao modo tradicional de tradução de uma língua para a outra, ou de texto fonte para texto alvo, este livro ilustrado, em seu uso do haiku e da caligrafia japonesa, em seu glossário e em sua explicação do wabi sabi, convida o leitor a considerar como a tradução compartilha ideias através e entre tempos e contextos culturais.

Palavras-chave: Intermediação. Transculturalidade. Tradução. Wabi Sabi. Literatura Infantil. 
RECEBIDO EM: 29 de janeiro de 2019

ACEITO EM: 06 de maio de 2019

PUBLICADO EM: julho 2019

$\mathrm{R}$ eibstein and Young's Wabi Sabi (2008) is a popular children's picture book that employs a range of media-including photography, drawing, collage and calligraphy - to tell the story of a Kyoto cat in search of the meaning of its name. These visual elements are accompanied by haiku poetry to explore the aesthetic worldview of the Japanese philosophy of wabi sabi: a philosophy that places value upon imperfection, transience and incompleteness. This paper investigates how such an intermedial text connects the implied child reader to the ideas of wabi sabi through translation, poetry and visual collage: a palimpsest of ideas that transcends traditional cultural boundaries. Moreover, it is argued that such overlapping relationships between form and content, poetry and philosophy, translation and trans-culturalism are part and parcel of the book's texture; a quality that requires the child reader to feel the various surfaces of its story. In following this idea, the search for the meaning of a name uncovers the limited capacity of words alone to describe who or how we are in the world.

Today's children are born to an era in which identities are increasingly composed in the overlapping folds of techno-culture and digital life, where our names often become disembodied entities connected in fleeting and fragile ways to the images and posts of social networking. In contrast, this paper examines a single text that offers an alternative approach to the search for self-knowledge. On first glance Mark Reibstein and Ed Young's picture book Wabi Sabi is a simple story about a Japanese cat that undertakes a journey in search of the origin of its name. However, the various narrative, poetic and visual devices within the story space combine in ways that draw the implied child reader into unexpected cultural, historical and philosophical terrain.

On rare occasions we are confronted with texts for children that are so visually engaging that it is initially quite difficult to take up a critical, analytical position in relation to it. This is doubly so with Wabi Sabi because, at its core, the story demands we pay attention not to logic and rationality but rather to nature, mysticism and the "feel" of things. Taking up this challenge, I am interested in how this picture book communicates such a textured and textural approach. I focus here on two aspects of intermediality. Firstly, I consider the notion that this text is an 
example of cultural translation, one that reflects a globalized world in which the mixing of different textual forms and meanings is increasingly commonplace. In so doing, I pose the idea that the cultural translation at play in this picture book opens up a space in which identity is liberated from a traditional, Western idea of the self as fixed by rational explanation and inquiry.

Further to this, I consider the picture book as a hybrid text that draws together a relationship between the philosophy of wabi sabi and the poetic tradition of the haiku. It is my contention that such overlapping relationships are part and parcel of the book's texture, in so far as this book requires the child reader to feel the various surfaces of its story. In so doing, the search for the meaning of a name uncovers the limited capacity of words alone to describe who or how we are in the world. It is only when we begin to consider identity as something that exists between the various folds of literature, image and imagination that the true meaning of the term wabi sabi is revealed.

The central narrative concerns an eponymous cat that undertakes a journey to uncover the meaning of her name. The cat discovers that her name "Wabi Sabi" refers to a Zen-Taoist philosophy to do with the beauty and value of impermanence, melancholy and imperfection; something which cannot really be described in words but which must be experienced in contact with rustic and everyday objects and experiences. Satisfied with this discovery, the cat returns home to curl up on a beloved old rattan mat.

Prose, poetry, informational and pictorial devices are all used to tell this story. In the style of a calendar or scroll the spreads in the picture book are designed in such a way that they are to be read from top to bottom (rather than plates we might scan with our eyes from left to right). As well as the short passages of prose, the spreads also feature haiku poetry in English and Japanese script. The philosophy of wabi sabi and the haiku tradition are briefly explained in a non-narrative style at the end of the book.

The pictorial elements are made using the technique of collage, and the original artworks utilize a range of recycled materials including plant fibres, paper and photography. Japanese calligraphy and ink-washes have also been used to create textured surfaces on several pages. Collage is a priori a form of intermediation, in the sense that it draws attention to the cutting, mixing and overlapping of various layers of storytelling through images and writing of different kinds; all of which is recomposed to create something new. To my mind it "adapts" scraps of paper and photography, drawing and calligraphy to the purposes of storytelling and in so doing lends a certain dense textuality to the book as a whole. 
However, Wabi Sabi is also intermedial beyond the level of style and image. The use of different kinds of writing - prose, Japanese characters, poetry - point to a textual field in which relationships between different modes of storytelling are established. Moreover, the basis for the story-an exploration of the ancient philosophy of wabi sabi for contemporary child readers - suggests a complex dialogic interlocking between past and present, as well as a cultural exchange between Western and non-Western thought and perception.

The combination of different forms of meaning-making that cross between Western and Japanese traditions marks this picture book out as a kind of text-in-translation; especially as that idea relates to the concepts of culture and identity. In the latter part of the $19^{\text {th }}$ century, translation studies became a recognized academic discipline. In the 1960s, at about the same time as identity politics and post-structuralist ways of thinking came into academic fashion, theories about translation took what is referred to as the "cultural studies" turn, in which scholars began to consider how translation is part of a wider matrix of relationships between cultural groups (CONWAY, 2012, p. 21-25).

Traditional approaches to literary translation have tended to focus on the idea of a source or original text and a target or translated equivalent, and this focus extends to the study of translation of children's texts (KLINGBERG, 1986; SHAVIT, 1986). In the case of Wabi Sabi, while there is no definitive source text behind the story as a whole, there are philosophical, aesthetic and poetic traditions that are translated for the implied child reader by its Western authors. In this manner it represents a hybrid text that, in its "original" form, relies on the translation of different semiotic elements from outside the cultural context in which it is produced.

There are implications for this sort of translation activity, particularly in the postcolonial era. As Susan Bassnett writes: “inequality of power relations (inequalities of economics, politics, gender and geography) is reflected in the mechanics of textual production... [whereby] translation can become submission to the hegemonic power of images created by the target culture" (2014, p. 5, see also PYM, 2014, p. 138-158). Accordingly, there is always a danger that adaptation or sampling of a philosophy, an image or a poetic tradition into a new textual form outside of the cultural context to which it refers can lead to the oversimplification and dilution of complex cultural and historical systems of meaning-making by more dominant or hegemonic groups.

I would argue that children's texts always involve some level of cultural translation, in so far as they are texts written by adults for child audiences. In this sense, ideas are 
communicated across cultural boundaries set up around age, education and social hierarchies as much as linguistic groupings. Put simply, adults translate the world on behalf of their child readers. According to this logic then, the sort of translation at work in Wabi Sabi is also a form of framing and gatekeeping through which adults mediate ideas about Japan, its history and culture to Western child readers.

The extent to which we might think of these relationships as uneven or disempowering is debatable. On one hand, Wabi Sabi depicts Japan through an Orientalist lens that privileges archaic images of the tea ceremony and the temple over that of modernity. Contemporary, urban Japan is only referred to once in the story: in a single spread, the cat observes a distant, street scene of traffic and city lights from the vantage point of a skyscraper window.

On the other hand, the difficulties the cat has in establishing for itself a fixed definition of its name is mirrored by the lack of a single intertext or myth that might sit behind the story and give it an origin. It signals the need to go beyond thinking of cultural translation in terms of what might be lost or gained, or the distance between source and target texts, towards an embrace of hybrid and overlapping planes of story and meaning.

In this light, the book could be said to signal a modern, globalized world in dialogue with older, more spiritual and philosophical engagements with existential questions. For instance, in the opening spread the cat's unseen owner has visitors to tea. It is this couple, clothed in Middle Eastern attire, that ask about the cat's name and set in motion the journey to uncover its origins. In so doing, the child reader is asked to consider the relationship between identity, place and experience.

In an era when people, ideas, finance and culture circulate and interact ever more frequently and rapidly across the earth (FEATHERSTONE, 1990), it is little wonder that the central question about identity posed in this picture book holds such importance. The processes of late modernity and globalization mean that transcultural experiences and affiliations are increasingly common. This leads to identities that can exist in the interstices between fixed ideas of nation, religion, language, as well as the various media these fields of identification might generate.

Homi K. Bhabha, in his 1994 book The Location of Culture, argues that post-modern literature, in particular, is a space in which experiences of hybridity come to the fore. Even more specifically, he sees translation as opening a "third space" in which multiple relationships between place, form, identity, history and so on become apparent. Wabi Sabi offers such a space: home and identity are concepts presented as complex and multi-layered on both a formal 
and a semantic level. It accepts as both possible and desirable that a child reader might look to hybrid visual and literary forms, as well as a non-Western philosophical tradition, to consider such ideas.

Viewed through the lens of cultural translation, Wabi Sabi highlights the potential meaning of the "inter" of intermediality, as a text that positions itself — and by extension its readers-between cultures and histories, languages and representational strategies. In his writing on intermediality Bernd Herzogenrath asks how various modes of textual production "negotiate their shapes, forms and contents" (2012, p. 3). In response, it is fair to say that the multimodality of Wabi Sabi is negotiated through a bricolage of form and narrative that in turn creates a bridge into a philosophy that, though ancient, has particular resonance for contemporary readers.

Andrew Juniper describes wabi sabi as a philosophy and an artistic form that emerges from the Tao and Zen religious traditions, with connections to the political and social developments of the Japanese imperial court (2011, p. 7-15). With its focus on the beauty to be found in humble, rustic objects, wabi sabi as a style or manner of artistic expression was a means through which those dispossessed of material wealth might be spiritually elevated.

Just as the eponymous cat finds his interlocutors evasive in their definitions of the name wabi sabi, Juniper points out that it evokes an "incredible melange of feelings" (2011, p. 47). Melancholy, languor and desolation, transience and mutability... these are all features of wabi sabi and yet, from a Western point of view, these are more often than not thought of in pejorative terms. Moreover, they are concepts rarely associated with children and childhood. And yet the cat, with her child-like inquisitiveness and even stubborn resolve to find the answer to her question, is positioned as an anthropomorphic child character within the text.

Juniper argues that wabi sabi can be best understood as a way of feeling the world, one that defies in many senses the rational, post-Enlightenment approaches favoured by Western thinking, being instead "a whetstone on which to sharpen spiritual awareness" (2011, p. 50). In fact, the repetitive and insistent questions posed by the cat to the various human and animal characters are never satisfied by standard responses in words alone. It is as if its name has become a floating signifier that cannot be pinned down by a simple definition in language. In the book it is only when the cat contemplates its reflection in a wooden bowl filled with warm soup that its existential appreciation of the name wabi sabi becomes apparent. Juniper writes that: 
Wabi sabi is an intuitive appreciation of a transient beauty in the physical world that reflects the irreversible flow of life in the spiritual world. It is an understated beauty that exists in the modest, rustic, imperfect or even decayed, an aesthetic sensibility that finds a melancholic beauty in the impermanence of all things (2011, p. 51).

The "austerity and simplicity" (2011, p. 51) that Juniper describes are politically contentious words in an era in which global financial crises have put the dominant economic system of market capitalism under great stress. They form part of the "feel" or texture of those societies in which material wealth is still very much aligned with success, happiness and fulfilment. In subtle ways Wabi Sabi is a picture book that challenges this seemingly hegemonic and naturalized relationship.

One of the ways it does this is through the materials used to make the original artwork that does so much of the storytelling in Wabi Sabi. Scraps of paper, bits of fur and plant fibres have been flattened, scrunched, teased and layered in order to produce a collage of tones and shapes that make up the coloured plates reproduced in the book. These are humble materials and they are assembled - quite roughly at times - to produce artwork of arresting beauty out of everyday scenes. Ironically perhaps, the hardcover version of the book is a permanent, precious artefact that recalls a philosophy about imperfection and impermanence.

There is an obvious connection between such a philosophy and the poetic tradition of the haiku that has been re-imagined in Wabi Sabi. Haiku emerged from older traditions of Japanese poetic writing in the late $17^{\text {th }}$ century (YASUDA, 2011, p. 141-184, HAKUTANI, 2009, p. 1-16). Haiku are three-line poems of five syllables, then seven, then five again. Nature is typically the most important theme, and as such the most celebrated poems deal with subjects as seemingly mundane as the change of seasons, birds, flowers, and so forth. As is the case with the philosophy of wabi sabi, this poetic form focuses attention on concepts around impermanence and imperfection, elevating aspects of rustic and agricultural life to an art form.

The appreciation of haiku in the West has unfolded over the past century. The Imagists, writing in the early 1900s, looked to this form as inspiration (KAWAMOTO, 1999, p. 709721). Later poets, including some involved in the Beat movement, also experimented with writing haiku (HAKUTANI, 2009, p. 89-109). Where Wabi Sabi and haiku is concerned, children are invited into a specialized knowledge about a specific Japanese poetic tradition and are given some access to the rich cultural heritage surrounding it. This is particular the case given the printing of the haiku in both English and Japanese, and the explication of the poetic form in the glossary at the end of the book. 
More broadly, the question of what the implied child reader will or will not understand is re-imagined by the authors' willingness to negotiate a relationship between different literary traditions that are themselves trans-cultural and trans-historical. In this manner, haiku can be understood as one of the many visual and literary techniques showcased in the book that connects the reader across time and place. The main focus of Wabi Sabi-the search for origin and identity-must therefore be said to exist "between the between" (HERZOGENRATH, 2012, p. 2) of its various narrative strategies, textual modalities and cultural positions.

Although predicated on literary transfer across source and target texts, Klingberg's notion (1986) that texts-in-translation are adapted to suit different cultural contexts is relevant here, in so far as each of the textual and narrative elements described above are part of an invitation to the implied reader to shift into a cultural and philosophical tradition that is, in all likelihood, new to them. Though it is a seemingly simple narrative that uses the well-practiced technique of collage to convey its story, the treatise on identity that it "translates" for Western child audiences is hybrid and complex.

For me, Wabi Sabi represents an intermediated poetics of identity that balances the

potency of the word with the textured layering of scraps and off-cuts, leaves, fur and skin, fabric and pattern. In the words of Herzogenrath it is both a "fractal surface" and a plane of “immanence", where connections between past and present, literary traditions, languages, cultural identities are pieced together in an unfolding and overlapping rhizomatic collage (2012, p. 2). As such, it invites its child reader into the ripples of the surface of a vast pond of image and texture; one in which the self is simultaneously reflected as fleeting, imperfect, melancholy, beautiful and wise.

\section{REFERENCES}

BASSNETT, Susan. Translation Studies. 4 ed. Routledge, 2014.

BHABHA, Homi K. The Location of Culture. 2 ed. Routledge, 2004.

CONWAY, Kyle. Cultural Translation. In: GAMBIER, Yves (ed.); DOORSLAER, Luc van (ed.). Handbook of Translation Studies. v. 3. Amsterdam: John Benjamin Publishing Company, 2012. p. 21-25.

FEATHERSTONE, Mike. Global Culture: Nationalism, Globalization and Modernity. Sage, 1990.

HAKUTANI, Yoshinobu. Haiku and Modernist Poetics. Palgrave MacMillan, 2009. 
HERZOGENRATH, Bernd. Travel in Intermediality, An Introduction. In:

HERZOGENRATH, Bernd (ed.). Travels in Intermedia(lity): Reblurring the Boundaries. Darmouth College Press, 2012. p.1-14.

JUNIPER, Andrew. Wabi Sabi: the Japanese Art of Impermanence. Tuttle Publishing, 2011.

KAWAMOTO, Koji. The Use and Disuse of Tradition in Bashō's Haiku and Imagist Poetry. Poetics Today, Durham, NC, v. 20, n. 4, p. 709-721, winter, 1999.

KLINGBERG, Götte. Children's Fiction in the Hands of the Translators. Liber/Gleerup, 1986.

PYM, Anthony. Exploring Translation Theories. Routledge, 2014.

REIBSTEIN, Mark; YOUNG, Ed. Wabi Sabi. Little Brown and Company, 2008.

SHAVIT, Zohar. Poetics of Children's Literature. University of Georgia Press, 1986.

YASUDA, Kenneth. Japanese Haiku: Its Essential Nature and History. Tuttle Publishing, 2011.

\footnotetext{
* Paul VENZO - PhD in literary studies and creative writing (2013) from Deakin University, Faculty of Arts and Education, titled Archipelago: A journey cross poetic islands of the self. MA in Cinema Studies (2002) from the University of Melbourne. Faculty Member of Deakin University, School of Communication and Creative Arts. Victoria, Australia. Academic curriculum: https://www.deakin.edu.au/about-deakin/people/paul-venzo https://blogs.deakin.edu.au/writing-and-literature/paul-venzo/ ORCID: https://orcid.org/0000-0002-3140-9832

E-mail: p.venzo@deakin.edu.au
} 